\title{
Water and Carbon Balance in Developing Fruit of the Satsuma Mandarin (Citrus unshu Marc.)
}

\author{
Taku Yano ${ }^{1,2}$, Tatsuo Kawano', Makoto Ohara', Yuichi Sato', Ryohei Kotegawa', \\ Hiroki Kagawa², Shuji Setoyama², Naoya Yokota², Ryosuke NomiYAMA², \\ Takuya ARAKI ${ }^{3}$, Eriko YASUNAGA ${ }^{4}$, Toshihiko EGUCHI ${ }^{5}$ and Masaharu KITANO ${ }^{2}$ \\ 'Oita Prefectural Agriculture, Forestry and Fisheries Research Center, Oita 879-7111, Japan \\ ${ }^{2}$ Faculty of Agriculture, Kyushu University, Fukuoka 812-0581, Japan \\ ${ }^{3}$ Faculty of Agriculture, Ehime University, Matsuyama, Ehime 790-8566, Japan \\ ${ }^{4}$ Institute for Sustainable Agro-ecosystem Services, Tokyo University, Tokyo 188-0002, Japan \\ ${ }^{5}$ Biotron Application Center, Kyushu University, Fukuoka 812-8581, Japan
}

(Received March 28, 2012; Accepted May 31, 2012)

In order to improve temperature and water management in the greenhouse cultivation of Satsuma mandarins, short-term water and carbon balance in intact Satsuma mandarin fruits was studied by measuring fruit expansive growth, $\mathrm{CO}_{2}$ and $\mathrm{H}_{2} \mathrm{O}$ gas exchange, sap flux into the fruit through the phloem and xylem, and ${ }^{13} \mathrm{C}$ partitioning. Seventy-one days after full bloom, with day/night temperature set at $28^{\circ} \mathrm{C} / 23^{\circ} \mathrm{C}$ and under fine weather conditions, sap flux through the xylem into the fruit showed a dynamic diurnal change which was related to changes of fruit volume. In leaves, ${ }^{13} \mathrm{C}$ partitioning decreased from 11:00 until 23:00, remaining constant thereafter, whereas in fruits, ${ }^{13} \mathrm{C}$ partitioning increased from 11:00 until 23:00, and then remained contrast. Investigating the cumulative water balance, $19 \%$ of water output was lost by fruit transpiration, whereas $81 \%$ contributed to fruit growth. In cumulative carbon balance, $39 \%$ of carbon output was lost by fruit respiration, whereas $61 \%$ contributed to fruit growth. Quantitative analyses of physiological responses to environmental conditions, as measured in this study, are essential for establishing energy-saving temperature management strategies.

Keywords : ${ }^{13} \mathrm{C}$-photosynthate, gas exchange, heat-ring, Satsuma mandarin

\section{INTRODUCTION}

The greenhouse cultivation of summer-harvested fruits, such as Satsuma mandarins and mangoes, requires a heated environment, because fruit development term is force to be in autumn, winter, and spring. For example, the main cropping type of Satsuma mandarin is harvested in summer, and must be grown in a heated greenhouse, with a nighttime temperature is maintained at $23^{-}$ $25^{\circ} \mathrm{C}$, from 50 to $120 \mathrm{~d}$ after full bloom, during active fruit growth; this occurs between January and April, which there is a large temperature difference between the greenhouse and the outside environment. In order to produce high quality fruits, farmers have no choice but to invest in heating. In recent years, however, large fluctuations and steep rises in oil prices have threatened fruit and vegetable cultivation, and energy-saving temperature management strategies are needed for evergreen developing fruits throughout the autumn and winter seasons.

Corresponding author: Takuya Araki, fax : +81-89-946-9526, e-mail : araki@agr.ehime-u.ac.jp 


\section{T. YANO ET AL.}

Research on the effect of temperature on the carbon balance of developing fruits has mainly focused on vegetables (Shishido et al., 1987, 1989); only a few studies on the temperature management of evergreen fruits have been reported.

Fruit production and quality is influenced by growth of the fruit and sugar accumulation, and this in turn depends on water and carbon balance within the fruit (Ho et al., 1987). In the greenhouse cultivation of Satsuma mandarins, production of high quality fruit requires precision in both irrigation and temperature management; irrigation is conventionally stopped approximately $60 \mathrm{~d}$ after full bloom, exposing the fruits to moderate drought stress from 90 to $100 \mathrm{~d}$ after full bloom. It is well known that certain vegetables must recieve restricted irrigation while the harvested organ is actively growing in order to produce a high quality product (Pate et al., 1977; People et al., 1985; Ho et al., 1987). In hydroponic tomatoes, the dynamics of sap fluxes through the phloem and xylem into the fruit, and water balance in the fruit, were evaluated under water deficit and salt stress conditions, which led to individual sap fluxes through the phloem and xylem (Ho et al., 1987; Araki et al., 2004), back flow of sap from the fruit through the xylem (Kitano and Araki, 2001), and a quantitative explanation on how a high-quality fruit is formed (Kitano and Araki, 2001). These results indicate the manner in which analyses of sap fluxes and carbon and water balance can provide important information for environmental management in greenhouse cultivation.

In the present paper, we study the short-term water and carbon balance in an intact fruit of the Satsuma mandarin, measuring expansive growth of the fruit, $\mathrm{CO}_{2}$ and $\mathrm{H}_{2} \mathrm{O}$ gas exchange, sap flux into the fruit through the phloem and xylem, and ${ }^{13} \mathrm{C}$ partitioning, with a view to improving temperature and water management in the greenhouse cultivation of Satsuma mandarins.

\section{MATERIAL AND METHODS}

\section{Plant material}

Seventeen-year-old, greenhouse-grown Satsuma Mandarins (Citrus unshu Marc.) were used in this study, with full bloom occurring on January 5, 2010, and harvest on July 5, 2010. Day/night temperature was set at $28^{\circ} \mathrm{C} / 23^{\circ} \mathrm{C}$, from 50 to $123 \mathrm{~d}$ after full bloom, and cultivation followed traditional practices. The short-term experiment was conducted under fine weather conditions, on March 17 and 18, 2010.

Gas exchange measurement in leaves and fruits

Gas exchange in the leaf was measured every $2 \mathrm{~h}$ from 8:00 to 18:00, by using a LI-6400 (LICOR, USA). Figure 1 shows a schematic diagram of a measurement of cylinder-type measurement chamber (diameter: $7.0 \mathrm{~cm}$, length: $7.0 \mathrm{~cm}$ ) in which humidity and temperature sensors (TR-3110, T\&D Corporation, Japan) were fixed and sufficient ventilation was provided by an air pump. Sampling of the air within the chamber, and monitoring of humidity and temperature were conducted every $4 \mathrm{~h}$. Following this, the air pump and ventilation opening were closed to maintain the chamber as a closed system for 10 min (Araki et al., 1997; Kitano et al., 1998 ). Before and after instigating the closed system, air in the chamber was sampled using a micro syringe, and relative humidity and temperature were monitored. $\mathrm{CO}_{2}$ concentration of the sampled air was determined using a gas chromatograph (GC-8APT and C-8A, Shimadzu Ltd., Japan) equipped with thermal conductivity detector. Fruit photosynthetic rate $\left(A_{\mathrm{F}} ; \mathrm{mmol} \mathrm{m}^{-3} \mathrm{~s}^{-1}\right)$ was be estimated as the differ-

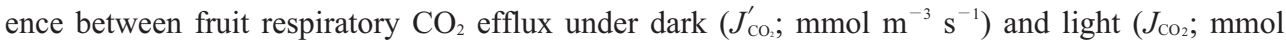
$\mathrm{m}^{-3} \mathrm{~s}^{-1}$ ) conditions, as

$$
A_{\mathrm{F}}=J_{\mathrm{CO}_{2}}^{\prime}-J_{\mathrm{CO}_{2}}
$$

As shown in Fig. $4, J_{\mathrm{CO}_{2}}^{\prime}$ was calculated using the relationship: $J_{\mathrm{CO}_{2}}^{\prime}=0.0378 T_{\mathrm{a}}-0.2936\left(r^{2}=\right.$ $0.60)$, where, $T_{\mathrm{a}}$ is air temperature within the chamber $\left({ }^{\circ} \mathrm{C}\right) ; J_{\mathrm{CO}_{2}}$ was calculated as fruit respiratory $\mathrm{CO}_{2}$ efflux measured under natural light conditions. 


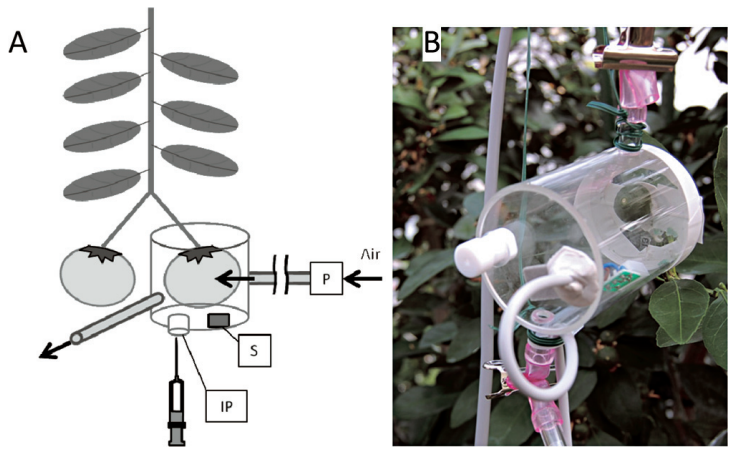

Fig. 1 Measurement system for $\mathrm{CO}_{2}$ and $\mathrm{H}_{2} \mathrm{O}$ gas exchanges in an intact fruit. (A) Schematic diagram of a fruit chamber. IP, insertion pore for sampling air in the chamber by micro syringe for the determination of $\mathrm{CO}_{2}$ concentration; $\mathrm{P}$, air pump for ventilating the chamber; $\mathrm{S}$, a sensor for monitoring relative humidity and air temperature in the chamber. (B) An intact fruit enclosed in the chamber.
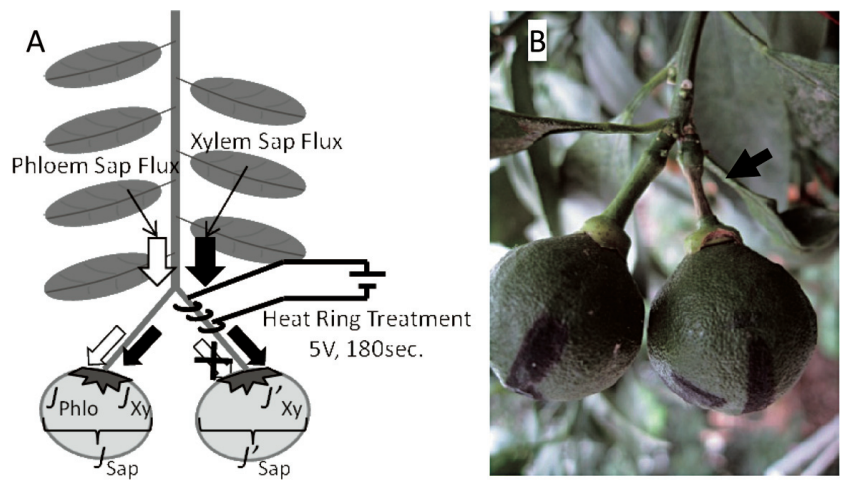

Fig. 2 Measurement of fruit water balance. (A)Schematic diagram of the heat-ring method for estimating sap flux $\left(J_{\text {Sap }}\right.$ and $\left.J_{\text {Sap }}^{\prime}\right)$, xylem sap flux $\left(J_{\text {Xy }}\right.$ and $\left.J_{\text {Xy }}^{\prime}\right)$, and phloem sap flux $\left(J_{\text {Phlo }}\right)$ into a fruit. (B) Fruits with non- heat-ring and heat-ring treatments (represented by an arrow) at $18 \mathrm{~h}$ after treatment.
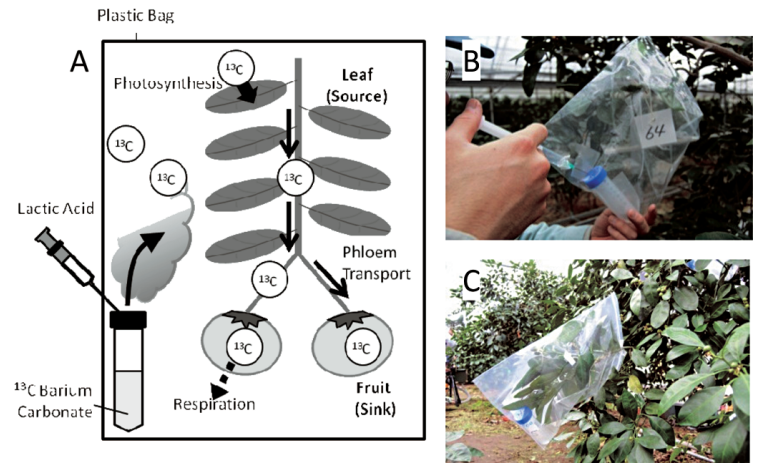

Fig. 3 Tracer experiment for estimating the partitioning of ${ }^{13} \mathrm{C}$-photosynthate in fruits. (A) Schematic diagram of the method for generating ${ }^{13} \mathrm{CO}_{2}$. (B) Injection of lactic acid into $\mathrm{Ba}^{13} \mathrm{CO}_{3}$. (C) ${ }^{13} \mathrm{CO}_{2}$ exposure. 


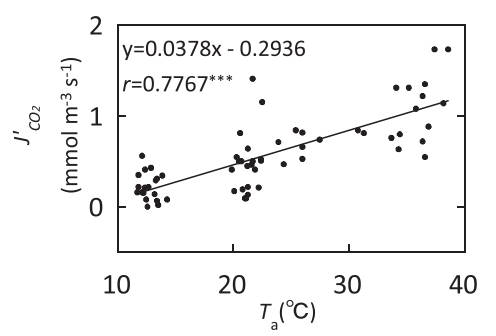

Fig. 4 Relationship between air temperature in the fruit chamber $\left(T_{\mathrm{a}}\right)$ and fruit respiratory $\mathrm{CO}_{2}$ efflux under dark conditions $\left(J_{\mathrm{CO}}^{\prime}\right)$.Vegetative stages of fruits were $30^{-90} \mathrm{~d}$ after full bloom.

\section{Measurement of fruit growth rate and pedicel sap flux}

The diameter $(D)$ of randomly selected fruits was measured using digital calipers. Long-term fruit volume growth was monitored every $10 \mathrm{~d}$, from $40 \mathrm{~d}$ after full bloom. Short-term fruit volume growth was determined by converting diameter into volume $\left(V_{\mathrm{F}}\right)$ using the relationship: $V_{\mathrm{F}}=$ $0.3812 D^{3}+1.746\left(r^{2}=0.99\right) . \quad V_{\mathrm{F}}$ was monitored every 2 or $4 \mathrm{~h}$ from $7: 00$; volume change $\left(\Delta V_{\mathrm{F}}\right)$ was determined by the difference between volume after 7:00 and that at 7:00. Based on water balance in the fruit, $G R F$ (the increase in volume of the fruits) was estimated to be equivalent to the difference between pedicel sap flux $\left(J_{\text {sap }} ; \mathrm{m}^{3} \mathrm{~m}^{-3} \mathrm{~s}^{-1}\right)$ towards the fruit and transpiratory water loss $\left(J_{\mathrm{WF}} ; \mathrm{m}^{3} \mathrm{~m}^{-3} \mathrm{~s}^{-1}\right)$ from the fruit. Therefore, $J_{\mathrm{Sap}}$ can be evaluated by the sum of $G R F$ and $J_{\mathrm{WF}}$ measured in the fruit chamber as:

$$
J_{\mathrm{Sap}}=G R F+J_{\mathrm{wF}}
$$

These variables $\left(G R F, J_{\mathrm{WF}}\right.$ and $\left.J_{\mathrm{Sap}}\right)$ in the intact fruit were represented as values per unit fruit volume. Figure 5 indicates the estimation of $J_{\mathrm{WF}}$ under natural light condition using the following relationship: $J_{\mathrm{WF}}=0.00044 T_{\mathrm{a}}^{2}+0.0114 T_{\mathrm{a}}-0.4786$. $J_{\mathrm{WF}}$ under dark conditions was estimated using the raw measurement data in Fig. 1.

The $J_{\text {sap }}$ is composed of phloem sap flux $\left(J_{\text {Phlo }} ; \mathrm{m}^{3} \mathrm{~m}^{-3} \mathrm{~s}^{-1}\right)$ and xylem sap flux $\left(J_{\mathrm{xy}} ; \mathrm{m}^{3} \mathrm{~m}^{-3}\right.$ $\left.\mathrm{s}^{-1}\right)$ as

$$
J_{\text {Sap }}=J_{\text {Phlo }}+J_{\mathrm{Xy}}
$$

For individual estimations of $J_{\text {Phlo }}$ and $J_{\mathrm{Xy}}$, phloem transport through the peduncle was blocked using heat-ring treatment, as displayed in Fig. 2-A. A constantan line was attached around the base of the peduncle, and heated at $5 \mathrm{~V}$ power for $180 \mathrm{~s}$ from the start of the experiment. A number of studies have indicated how heat-ring treatments $\left(>60^{\circ} \mathrm{C}\right)$ inhibit phloem transport by killing phloem cells, without significantly affecting xylem water transport for leaf transpiration (Neales and Incoll, 1968; Ehret and Ho, 1986; Grusk et al., 1990; Lang, 1990; Goldschmidt and Huber, 1992;Tazuke, 1993; Araki et al., 2004); pedicel sap flux on the heat-ringed peduncle $\left(J_{\text {Sap }}^{\prime} ; \mathrm{m}^{3}\right.$ $\mathrm{m}^{-3} \mathrm{~s}^{-1}$ ) was therefore considered to be brought about through xylem transport only and to be equivalent to $J_{\mathrm{Xy}}$ on the non-heat-ringed peduncle such that:

$$
J_{\text {Sap }}^{\prime}=J_{\mathrm{xy}}
$$

$J_{\text {Sap }}^{\prime}$ can be also evaluated on basis of Eq. (2) as:

$$
J_{\mathrm{Sap}}^{\prime}=G R F^{\prime}+J_{\mathrm{wF}}^{\prime}
$$

where $G R F^{\prime}$ and $J_{\mathrm{wF}}^{\prime}$ are the $G R F$ and $J_{\mathrm{wF}}$ measured on the heat-ringed peduncle using digital calipers, respectively. Thus, from Eqs. (3) and (4), phloem sap flux ( $\left.J_{\text {Phlo }}\right)$ through the pedicel on the non-heat-ringed peduncle and on the $J_{\text {Sap }}^{\prime}$ on the heat-ringed peduncle can be estimated as: 


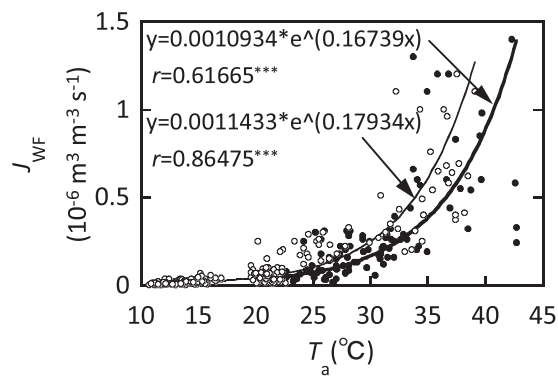

Fig. 5 Relationship between air temperature in the fruit chamber $\left(T_{\mathrm{a}}\right)$ and fruit transpiration $\left(J_{\mathrm{WF}}\right)$ under dark conditions $(\bigcirc)$ and natural light conditions $(\bigcirc)$. Vegetative stages of fruits were $30-90 \mathrm{~d}$ after full bloom.

$$
J_{\text {Phlo }}=J_{\text {Sap }}-J_{\text {Sap }}^{\prime}
$$

Analysis of the partitioning of ${ }^{13} \mathrm{C}$-photosynthates

A simple source-sink unit model was constructed to analyze the partitioning of ${ }^{13} \mathrm{C}$ photosynthates, and thereby elucidate the dynamics of carbon translocation from leaves to fruits. A source-sink unit, generated in the summer of 2009 as a shoot, consisted of 2 fruits and 7 leaves by the summer of 2010 (Fig. 3). During ${ }^{13} \mathrm{C}$ feeding, the unit was enclosed within a $3 \mathrm{~L}$ vinyl film bag, sealed to absorb ${ }^{13} \mathrm{C}$ efficiently, and a $50 \mathrm{~mL}$ volume test tube holding $0.5 \mathrm{~g}$ of $\mathrm{Ba}^{13} \mathrm{CO}_{3}$ (Fig. 3) was placed into the bag. At 9:00, $10 \mathrm{~mL}$ of $10 \%$ lactic acid was injected into the test tube (within the bag) using a disposable syringe, which subsequently led to ${ }^{13} \mathrm{CO}_{2}$ generation as follows:

$$
\mathrm{Ba}^{13} \mathrm{CO}_{3}+2 \mathrm{C}_{3} \mathrm{H}_{6} \mathrm{O}_{3} \rightarrow\left(\mathrm{CH}_{3} \mathrm{CH}(\mathrm{OH}) \mathrm{COO}\right)_{2}-\mathrm{Ba}+\mathrm{H}_{2} \mathrm{O}+{ }^{13} \mathrm{CO}_{2}
$$

After $2 \mathrm{~h}$ exposure of ${ }^{13} \mathrm{CO}_{2}$, the vinyl film bag was removed. In a preliminary experiment, the $\mathrm{CO}_{2}$ concentration in the bag was checked and was observed to be approximately $1,000 \mu \mathrm{L} \mathrm{L}^{-1}$. Three source-sink units were harvested and separated into leaves, stem, and 2 fruits, at $4 \mathrm{~h}$ intervals from 11:00 to 7:00 (next moring). The separated samples were oven dried for several days at $80^{\circ} \mathrm{C}$, and dry weight was determined. The dry samples were ground to a powder using vibration mill (Shake Master, Bio Medical Science Ltd., Japan). The quantity of ${ }^{13} \mathrm{C}$ was determined using a gas chromatography combustion isotope ratio mass spectrometer (Integra CN, Sercon Ltd., UK).

Verification of the heat-ring method

Use of the heat-ring method for the individual estimations of $J_{\mathrm{xy}}$ and $J_{\text {Phlo, }}$, necessitates verification that the heat-ring treatment on the peduncle inhibits phloem transport through the stem. Phloem transport of ${ }^{13} \mathrm{C}$-photosynthatesin heat ringed fruit was therefore compared with that of the non-heat-ringed fruit. The experiment was conducted at $85 \mathrm{~d}$ after bloom. Source-sink units were exposed to ${ }^{13} \mathrm{CO}_{2}$ from 11:00 to 13:00.

Estimation of integrated translocation for a fruit

Integrated translocation for a fruit was estimated as

$$
\Sigma T L=\Sigma J_{\mathrm{CO}_{2}}^{\prime}+D M_{\mathrm{F}}-\Sigma A_{\mathrm{F}}
$$

where, $\Sigma T L, D M_{\mathrm{F}}$, are the integrated translocation for a fruit and dry matter of a fruit, respectively.

\section{RESULTS}

\section{Heat-ring treatment}

Figure 6 indicates the manner in which the heat-ring method was verified through ${ }^{13} \mathrm{C}$ - 


\section{T. YANO ET AL.}

photosynthate translocation in a source-sink unit. Following a ${ }^{13} \mathrm{CO}_{2}$ feed, ${ }^{13} \mathrm{C}$ partitioning was highest in the leaf, and was $18 \%$ and $12 \%$ of total ${ }^{13} \mathrm{C}$ content in a unit for the stem and non-heatringed fruit, respectively; and ${ }^{13} \mathrm{C}$ partitioning of heat-ringed fruit was zero. At $19 \mathrm{~h}$ after a ${ }^{13} \mathrm{CO}_{2}$ feed, non-heat-ringed fruit accumulated a significant amount of ${ }^{13} \mathrm{C}$, but heat-ringed fruit accumulated very little amount of ${ }^{13} \mathrm{C}$. Thus, we verified that the heat-ring treatment on the Satsuma mandarin peduncle can inhibit the phloem transport of photosynthates through the stem.

Dynamics of fruit growth, components of fruit water and carbon balance

Figure 7 displays fruit volume and fruit growth rate from 40 to $150 \mathrm{~d}$ after full bloom. The growth rate of fruit was highest at $100 \mathrm{~d}$ after full bloom $\left(1.06 \mathrm{~cm}^{3}\right.$ day $\left.{ }^{-1}\right)$ during the experiment, and the rate at $71 \mathrm{~d}$ after full bloom in the short-term experiment showed a significant increase of fruit volume $\left(0.6 \mathrm{~cm}^{3}\right.$ day $\left.^{-1}\right)$.

Figure 8-A shows diurnal changes in environmental conditions at $71 \mathrm{~d}$ after full bloom, $\left(R_{\mathrm{s}}\right.$, solar radiation; $T_{\mathrm{a}}$, air temperature; and $V P D$, vapor pressure deficit). Weather conditions on the day of the experiment day (March 17) were fine. In the morning, $R_{\mathrm{s}}$ increased gradually and reached a maximum in the early afternoon. $T_{\mathrm{a}}$ was maintained at approximately $25^{\circ} \mathrm{C}$ in the daytime and $23^{\circ} \mathrm{C}$ at night; $V P D$ increased with $R_{\mathrm{s}}$ in the daytime and decreased in evening.

Figure 8-B displays diurnal changes in leaf gas exchange at $71 \mathrm{~d}$ after full bloom $\left(A_{\mathrm{L}}\right.$, leaf photosynthetic rate; $T r_{\mathrm{L}}$, leaf transpiration rate; and $G_{\mathrm{s}}$, leaf stomatal conductance). Xylem water potential of the leaf measured in a pressure-chamber shortly before sunrise, was $-0.73 \pm 0.02 \mathrm{MPa}$ (data not shown). An increase in $R_{\mathrm{s}}$ in the morning induced rises in $A_{\mathrm{L}}, \operatorname{Tr}_{\mathrm{L}}$ and $G_{\mathrm{s}} ; A_{\mathrm{L}}$ showed a particularly large increase. At approximately midday, $A_{\mathrm{L}}, \operatorname{Tr}_{\mathrm{L}}$ and $G_{\mathrm{s}}$ began to decrease rapidly, even under the bright conditions.

Figure 8-C displays diurnal changes in fruit volume. Shrinkage in the fruit volume was occurred from the early morning until the early afternoon, and growth in fruit volume occurred from

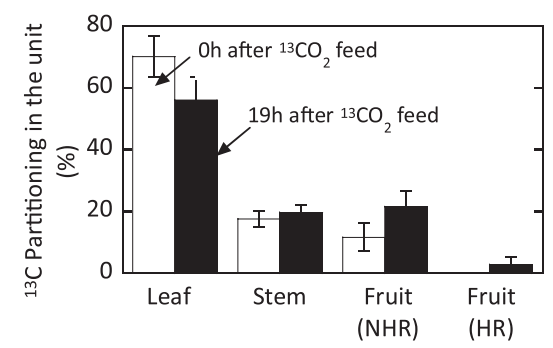

Fig. 6 Verification of the heat-ring method for ${ }^{13} \mathrm{C}$-photosynthate translocation in a source sink unit. The source-sink unit is indicated in Fig. 2. NHR, non-heat-ringed, HR, heat-ringed. Values represent the mean of 4 or 5 source-sink units; vertical bars indicate standard errors.

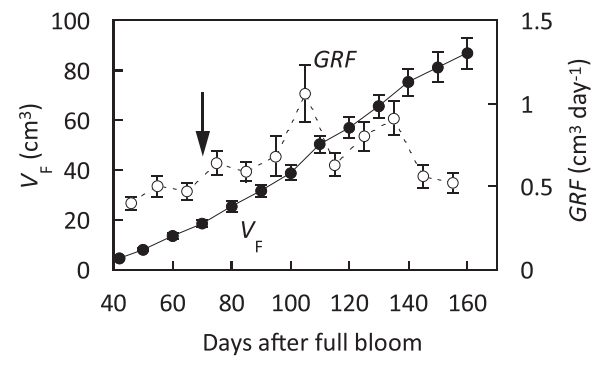

Fig. 7 Fruit volume $\left(V_{\mathrm{F}}\right)$ and growth rate of fruit $(G R F)$. The short-term experiment is represented by an arrow. Values represent the mean of 3 plants; vertical bars indicate standard errors. 

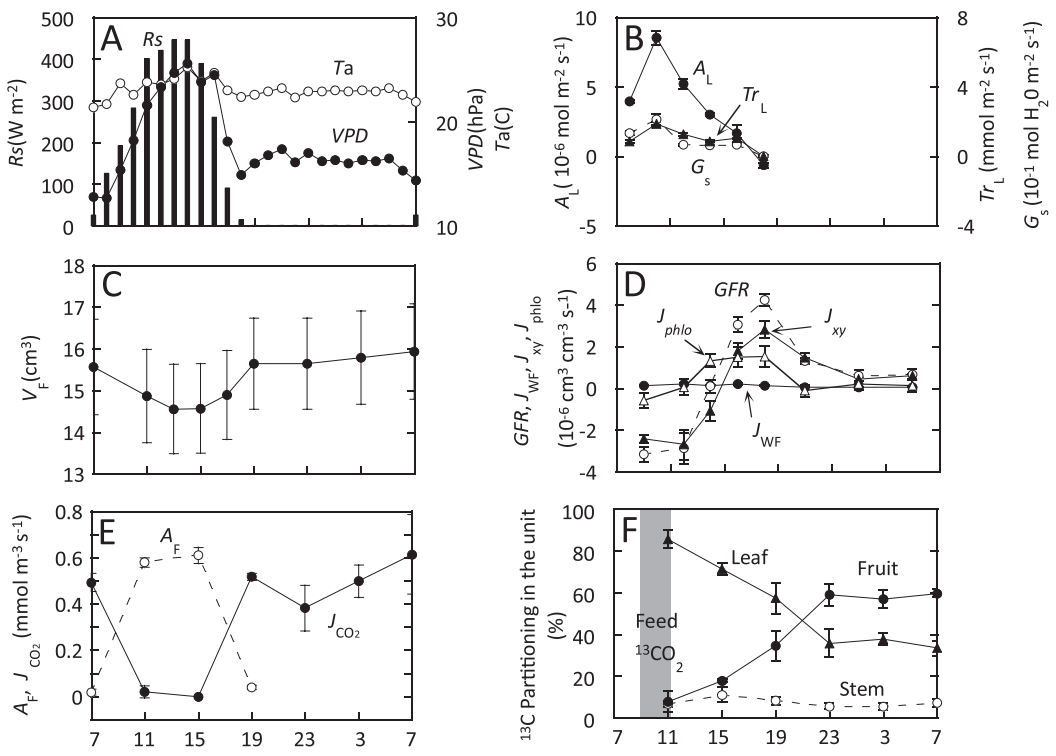

Time

Fig. 8 Diurnal changes of environmental factors (A), gas exchange rates in the leaf, (B) fruit volume, (C) fruit water balance, (D) fruit gas exchange, and (E) ${ }^{13} \mathrm{C}$ partitioning in the unit $(\mathrm{F})$ at $71 \mathrm{~d}$ after full bloom. $R_{\mathrm{s}}, T_{\mathrm{a}}$ and $V P D$ for solar radiation, air temperature, and vapor pressure deficit, respectively; $A_{\mathrm{L}}, G_{\mathrm{s}}$ and $T r_{\mathrm{L}}$ for leaf photosynthetic rate, leaf stomatal conductance and leaf transpiration rate; respectively; $A_{\mathrm{F}}, J_{\mathrm{CO}_{2}}$, and $V_{\mathrm{F}}$ for estimated fruit photosynthetic rate, net $\mathrm{CO}_{2}$ efflux of fruit, and fruit volume, respectively; GFR, $J_{\mathrm{Phlo}}, J_{\mathrm{WF}}$, and $J_{\mathrm{Xy}}$ for fruit growth rate, phloem sap flux, fruit transpiration, and xylem sap flux, respectively. Values represent mean of 3 plants; vertical bars indicate standard errors.

late afternoon, continuing through the night time.

Figure 8-D indicates diurnal changes of fruit water balance at $71 \mathrm{~d}$ after full bloom $(G R F$, growth rate of fruit; $J_{\mathrm{WF}}$, fruit transpiration; $J_{\mathrm{Xy}}$, xylem sap flux; and $J_{\text {Phlo, }}$ phloem sap flux). From early morning until early afternoon, $G R F$ and $J_{\mathrm{Xy}}$ had negative values, thereafter, they showed a clear peak in the early nighttime and remained at a low level until next morning. GRF showed a similar diurnal pattern to $J_{\mathrm{xy}}$. In the early morning, $J_{\text {Pho }}$ had a negative value close to zero, and increased until the early afternoon, decreasing by midnight. $J_{\text {Pho }}$ showed similar diurnal pattern to $T_{\mathrm{a}} . J_{\mathrm{WF}}$ remained at close to zero throughout the experiment.

Figure 8-E shows gas exchange in the fruit at $71 \mathrm{~d}$ after full bloom $\left(A_{\mathrm{F}}\right.$, estimated fruit photosynthetic rate; and $\mathrm{JcO}_{2}$, net $\mathrm{CO}_{2}$ efflux of fruit). $A_{\mathrm{F}}$, as calculated from Eq.(1), increased in the morning and decreased at night. By contrast, $J \mathrm{CO}_{2}$ decreased in the early morning and increased in the evening.

Figure 8-F shows diurnal changes in ${ }^{13} \mathrm{C}$ partitioning in the unit, at $71 \mathrm{~d}$ after full bloom. Shortly after feeding with ${ }^{13} \mathrm{CO}_{2}$, leaves contained abundant ${ }^{13} \mathrm{C}$ assimilates, whereas the stem and fruit contained few ${ }^{13} \mathrm{C}$ assimilates. In the leaf, ${ }^{13} \mathrm{C}$ partitioning decreased from 11:00 until 23:00, and remained constant thereafter, whereas in the fruit, ${ }^{13} \mathrm{C}$ partitioning increased from 11:00 until 23:00, and remained constant thereafter. In the stem, ${ }^{13} \mathrm{C}$ partitioning remained at a relatively low and constant values.

\section{Cumulative water and carbon balance}

Figure 9 shows the cumulative water balance and carbon balance in an intact fruit at $71 \mathrm{~d}$ after full bloom ( $\Sigma J_{\mathrm{Xy}}$, integrated xylem sap flux; $\Sigma J_{\mathrm{Phl}}$, integrated phloem sap flux; $\Sigma J_{\mathrm{WF}}$ integrated fruit transpiration; $\Sigma G R F$, integrated fruit growth rate; $\Sigma A_{\mathrm{F}}$, integrated fruit photosynthesis; $\Sigma T L$, 

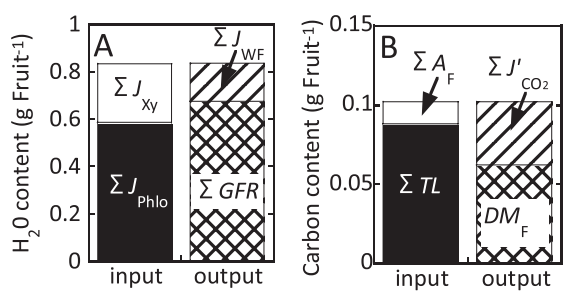

Fig. 9 Cumulative water balance (A) and carbon balance (B) in an intact fruit, at $71 \mathrm{~d}$ after full bloom. $\Sigma J_{\mathrm{Xy}}, \Sigma J_{\mathrm{Phlo}}, \Sigma J_{\mathrm{WF}}$, and $\Sigma G F R$ for integrated xylem sap flux, integrated phloem sap flux, integrated fruit transpiration, and integrated fruit growth rate, respectively; $\Sigma A_{\mathrm{F}}, \Sigma T L, \Sigma J_{\mathrm{CO}}^{\prime}$, and $D M_{\mathrm{F}}$ for integrated fruit photosynthesis, integrated translocation for a fruit, integrated fruit respiration, and dry matter of the fruit, respectively.

integrated translocation for a fruit; $\Sigma J_{\mathrm{CO} \text {, }}^{\prime}$, integrated fruit respiration; and $D M_{\mathrm{F}}$, dry matter of a fruit).

Water input of the fruit was divided as $30 \%$ for sap accumulation via the xylem and $70 \%$ for sap accumulation via the phloem. Water output of the fruit was divided as $19 \%$ for fruit transpiration and $81 \%$ for sap accumulation in the fruit. In other words, $19 \%$ of the water output was lost by fruit transpiration, whereas $81 \%$ of water output was contributed to fruit growth. Carbon input of the fruit was divided as $14 \%$ for the fruit photosynthesis and $86 \%$ for translocation into the fruit. Carbon output was divided as $39 \%$ for fruit respiration and $61 \%$ for dry matter accumulation within the fruit. Thus, $39 \%$ of carbon output was lost by fruit respiration, whereas $61 \%$ of carbon output was contributed to fruit growth.

\section{DISCUSSION}

It is well known that drought stress affects many physiological processes in plants. In the short-term experiment of present study, the drought stress level measured as xylem water potential was $-0.73 \pm 0.02 \mathrm{MPa}$ at shortly before sunrise (data not shown). This value was considered to be a moderate drought stress level (Yakushiji et al., 1998) and valid for the production of high quality Satsuma mandarin fruits.

In the daytime, a high evaporative demand leads to excessive leaf transpiration, low xylem water potential, and water stress, which can induce sap backflow from the fruits through the xylems, and resulting in fruit shrinkage (Fig. 8-A, B and C). After peak shrinkage, substantial increases in fruit growth rate and pedicel sap flux accompany both phloem sap flux towards the fruit and ${ }^{13} \mathrm{C}$ increase in the fruit up until midnight (Fig. 8-C, D, E). Thereafter, from midnight to sunrise, sap fluxes and ${ }^{13} \mathrm{C}$ increase in the fruit remain at low constant values. These physiological phenomena suggest that environmental regulation between early afternoon and midnight is important for accumulation of mass in developing Satsuma mandarin fruits.

Measurements of expansive growth and sap flux revealed that the majority (81\%) of sap flux towards the fruit $\left(\Sigma J_{\mathrm{Xy}}+\Sigma J_{\mathrm{Phlo}}\right)$ contributed to fruit growth, and transpiratory water loss from the fruit $\left(\Sigma J_{\mathrm{WF}}\right)$ amounted to only $19 \%$ of the pedicel sap flux towards the fruit (Fig. 9-A). These results are similar to those found in tomato (Araki et al., 1998, 2004), where sap backflow from fruits, through the xylems, result in fruit shrinkage.

The carbon budget of developing fruit depends on the photosynthetic products from leaves or translocation from leaf to fruit, and is also influenced by fruit photosynthesis and respiration. Fruit photosynthesis has been documented in a wide range of spices (Flinn et al., 1977; Blanke and Lenz, 1989). Photosynthetic $\mathrm{CO}_{2}$ fixation in green apples (Malusdomestica Borkh.), olives (Oleaeuropea L.), lemons (Citrus limon, Burm. f. ) and oranges (C. sinensis, Osbeck) is conserved at $20-80 \%$ of the $\mathrm{CO}_{2}$ released by respiration in the dark, depending on the stage of development (Bean and 
Todd, 1960; Bean et al., 1963; Blanke and Lenz, 1989). In the present study, photosynthetic $\mathrm{CO}_{2}$ fixation in the fruit of Satsuma mandarin at $71 \mathrm{~d}$ after full bloom was $35 \%$ of the $\mathrm{CO}_{2}$ released by respiration in the dark (Fig. 9-B).

Kubota and Motoyama (1972) used a ${ }^{14} \mathrm{C}$ tracer in Satsuma mandarins to examine the effect of fruit-bearing on the translocation of the photosynthate. ${ }^{14} \mathrm{CO}_{2}$ was fed to the fruit-bearing shoot, or to a non-fruit-bearing shoot, and its translocation was observed. In the fruit-bearing shoot, the ${ }^{14} \mathrm{C}$-assimilation product was predominantly retained within the treated shoot itself; very little was distributed to other shoots and roots. Fruit growth in the fruit-bearing shoot may be strongly influenced by the leaves attached to the shoot itself, and these results suggest that the ${ }^{13} \mathrm{C}$ tracer method, as modeled by the source-sink unit in a mature tree, is suitable for the measurement of carbon balance.

These basic analyses, such as the carbon budget of developing fruit that is dependent on temperature, has mainly been studied in nursery vegetables, using the ${ }^{14} \mathrm{C}$ tracer method (Shishido et al., 1987, 1989). In the present study, a ${ }^{13} \mathrm{C}$ tracer method was adopted because of the necessity for dealing with mature-aged trees grown in a greenhouse. In this study, ${ }^{13} \mathrm{C}$ distribution was $85 \%$ in leaves, $7 \%$ in the stem, and $8 \%$ in fruits, shortly after a ${ }^{13} \mathrm{C}$ feed. This result suggests that fruit development mainly depends on leaf photosynthesis and carbon translocation from leaf to fruit, and that fruit photosynthesis has a negligible contribution towards fruit development. Fruit photosynthesis has been shown to contribute $15 \%$ of the total carbohydrates used in fruit development in blueberries (Vacciniumashei Reade) (Birkhold et al., 1992). In the present study, Satsuma mandarin fruit photosynthesis at $71 \mathrm{~d}$ after full bloom was shown to contribute $16 \%$ of the total carbohydrates used in fruit development (Fig. 9), the contributions of fruit photosynthesis may, however, vary widely during fruit development.

Respiratory rates on a dry-weight basis typically decrease during fruit development. Although this process provides energy for metabolism, growth, and maintenance processes within the fruit (Jone, 1981), it reduces the amount of carbon available for the accumulation of dry matter and sugar. For example, DeJong and Walton (1989) estimated that peach fruit (Prunuspersica (L) Batsch) respired $16-21 \%$ of their total fruit dry weight during development. In this study, Satsuma mandarin fruit at $71 \mathrm{~d}$ after full bloom showed relatively high respired at much higher $65 \%$ of their own total fruit dry weight.

These results suggest that the development of Satsuma mandarin fruit at early stage, with moderate water stress may be regulated by leaf photosynthesis, carbon translocation from leaf to fruit via phloem and fruit respiration. Quantitative analyses of physiological responses to environmental conditions, as measured this study, are essential for establishment of energy-saving temperature management strategies.

This research was supported by Research and Development Projects for Application in Promorting New Policy of Agriculture, Forestry and Fisheries (No. 21061) from the Ministry of Agriculture, Forestry and Fisheries of Japan and by Grants-in-Aid for Scientific Research (No.2338015) from the Japan Society for Promotion of Science.

\section{REFERENCES}

Araki, T., Eguchi, T., Wajima, T., Yoshida, S., Kitano, M. 2004. Dynamic analysis of growth, water balance and sap fluxes through phloem and xylem in a tomato fruit: Short-term effect of water stress. Environ. Control in Biol. 42: 225-240.

Araki, T., Kitano, M., Hamakoga, M., Eguchi, H. 1998. Analysis of growth, water balance and respiration of tomato fruits under water deficit by using a multiple chamber system. Biotronics 27: 61-68. 


\section{T. YANO ET AL.}

Araki, T., Kitano, M., Eguchi, H. 1997 Respiration, sap flux, water balance and expansive growth in tomato fruit. Biotronics 26: 95-102.

Bean, R. C., Porter, G. G., Barr, B. K. 1963. Photosynthesis and respiration in developing fruit. III. Variation in photosynthetic capacities during color change in Citrus. Plant Physiol. 38: 285-290.

Bean, R. C., Todd, G. W. 1960. Photosynthesis and respiration indeveloping fruits. $\mathrm{I}^{14} \mathrm{CO}_{2}$ uptake by young orange in light and dark. Plant Physiol. 35: 425-429.

Birkhold, K. T., Koch, K. E., Darnell, R. L. 1992. Carbon and nitrogen economy of developing rabbiteye blueberry fruit. J. Am. Soc. Hort. Sci. 117: 139-145.

Blanke, M. M., Lenz, F. 1989. Fruit photosynthesis. Plant Cell Environ. 12: 31-46.

DeJong, T. M., Walton, E. F. 1989. Carbohydrate requirements of peach fruit growth and respiration. Tree Physiol. 5: 329-335.

Ehret, D. L., Ho, L. C. 1986. Effect of osmotic potential in nutrient solution on diurnal growth of tomato fruit. J. Exp. Bot. 37: 1294-1302.

Flinn, A. M., Atkins, C. A., Pate, J. S. 1977. Significance of photosynthetic and respiratory exchanges in the carbon economy of the developing pea fruit. Plant Physiol. 60: 412-418.

Goldschmidt, E. E., Huber, S. C. 1992. Regulation of photosynthesis by end product accumulation inleaves of plants storing starch, sucrose, and hexose sugars. Plant Physiol. 99: 1443-1448.

Grusk, M. A., Delrot, S., Ntsika, G. 1990. Short-term effects of heat-girdles on source leaves of Viciafaba: analysis of phloem loading and carbon partitioning parameters. J. Exp. Bot. 41: 1371-1377.

Ho, L. C., Grange, R. I., Picken, A. J. 1987. An analysis of the accumulation of water and dry matter in tomato fruit. Plant Cell Environ. 10: 157-162.

Jones, H. G. 1981. Carbon dioxide exchange of developing apple (Maluspumila Mill) fruits. J. Expt. Bet. 32: 1203-1210.

Kitano, M., Araki, T. 2001. Environmental effects on dynamics of fruit growth and photoassimilate translocation in tomato plants II. Analysis of phloem sap and xylem sap fluxes and fruit water balance. Environ. Control Biol., 39: 43-51.

Kitano, M., Araki, T., Eguchi, H. 1998. Environmental effects on dynamics of fruit growth and photoassimilate translocation in tomato plants I. Effects of irradiation and day/night temperature. (in Japanese text) Environ. Control Biol. 36: 225-240.

Kitano, M., Araki, T., Eguchi, H. 1998. Temperature dependence of postphloem transport regulated by respiration in tomato fruits. Biotronics 27: 33-39.

Kubota, S., Motoyama, E. 1972. The effect of fruit-bearing on the translocation and distribution of ${ }^{14} \mathrm{C}$ photosynthates in Satsuma Mandarin trees. Bull. Shikoku Agri. Exp. Sta. 24: 27-40.

Lang, A. 1990. Xylem, phloem and transpiration flows in developing apple fruits. J. Exp. Bot. 41: 645-651.

Neales, T. F., Incoll, L. D. 1968. The control of leaf photosynthesis rate by the level of assimilate concentration in the leaf : a review of hypothesis. Bot. Rev. 34: 107-125.

Pate, J. S., Sharkey, P. J., Atkins, C. A. 1977. Nutrition of a developing legume fruit, functional economy in terms of carbon, nitrogen, water. Plant Physiol. 59: 506-510.

People, M. B., Pate, J. S., Atkins, C. A., Murrang, D. R. $1985 . \quad$ Economy of water, carbon and nitrogen in the developing cowpea. Plant Physiol. 77: 142-147.

Shishido, Y., Seyama, N., Imada, S., Hori, Y. 1989. Carbon budget in tomato plants as affected by night temperature evaluated by steady state feeding with ${ }^{14} \mathrm{CO}_{2}$. Ann. Bot. 63: 357-367.

Shishido, Y., Challa, H., Krupa, J. 1987. Effect of temperature and light on the carbon budget of young cucumber plants studied by steady-state-feeding with ${ }^{14} \mathrm{CO}_{2}$. J. Exp. Bot. 38: 1044-1054.

Tazuke, A. 1993. Relationships between growth in volume and respiration of cucumber fruit after heatgirdring the peduncle. J. Jpn. Soc. Hortic. Sci. 62: 135-142.

Yakushiji, H., Morinaga, K., Nonami, H. 1998. Sugar accumulation and partitioning in Satsuma mandarin tree tissues and fruit in response to drought stress. J. Am. Soc. Hort. Sci. 123: 719-726. 